\title{
Nuorena turvapaikanhakijana Suomessa
}

Honkasalo, Veronika, Maiche, Karim, Onodera, Henri, Peltola, Marja \& Suurpää, Leena (toim.)

Nuorten turvapaikanhakijoiden elämää vastaanottovaiheessa.

Helsinki: Nuorisotutkimusverkosto, 2017

Saatavissa verkkojulkaisuna: http://www.nuorisotutkimusseura.fi/images/julkaisuja/ nuorten_turvapaikanhakijoiden_elamaa_vastaanottovaiheessa.pdf

Päivikki Rapo

$\mathrm{N}$ uorten turvapaikanhakijoiden elämää vastaanottovaiheessa on Nuorisotutkimusseuran vuonna 2017 julkaisema kirja, joka kokoaa yhteen samannimisen kirjoitussarjan artikkelit. Julkaisun ovat toimittaneet nuorisotutkijat Veronika Honkasalo, Karim Maiche, Henri Onodera, Marja Peltola ja Leena Suurpää. Sen tekstit ovat luonteeltaan niin sanottuja näkökulmia. Näitä kuvaillaan artikkeleiden yhteydessä seuraavasti: "Näkökulma avaa Nuorisotutkimusverkostossa tehtävän tutkimuksen tuloksia yhteiskunnallisiksi puheenvuoroiksi ja kannanotoiksi. Näkökulmat sisältävät paitsi uutta tietoa nuorista, myös politiikkaan ja käytännön toimintaan suunnattuja ehdotuksia." Julkaisu koostuu 16 artikkelista ja yhdestä liitteestä. Se on saatavilla sekä verkossa että painettuna.

Kirjoitussarjan taustalla on Nuorisotutkimusverkoston, Pelastakaa Lapset ry:n ja Valtion nuorisoasiain neuvottelukunnan yhteistyössä toteuttama tutkimus- ja vapaaehtoishanke. Nuorisotutkijat Veronika Honkasalo, Karim Maiche, Henri Onodera, Marja Peltola ja Leena Suurpää osallistuivat tammi-heinäkuussa 2016 erään pääkaupunkiseudulla sijaitsevan asumisyksikön toimintaan. Siellä he järjestivät muun muassa retkiä 
ja avointa nuorisotoimintaa asumisyksikön nuorille. Yksikössä asui kyseisellä aikavälillä noin 40 nuorta, 16-17-vuotiasta miestä. Kenttähavaintojen lisäksi artikkeleiden aineistona toimii noin 20 asumisyksikön nuorten ja työntekijöiden haastattelua. Tutkijaryhmän artikkeleiden ohella kirjoitussarjassa kuullaan myös muita asiantuntijoita, kuten muualla Suomessa nuorten turvapaikanhakijoiden parissa tutkimusta tehneiden tutkijoiden analyysejä sekä nuorten turvapaikanhakijoiden kanssa työskentelevien ajatuksia ja kokemuksia. Kirjaa rikastuttavat kiinnostavat, nuorten turvapaikanhakijoiden elämästä kertovat valokuvat, joista valtaosan on ottanut nuori turvapaikanhakija Mostafa Mohammad Ali.

Julkaisu on Nuorisotutkimusseuralta ennen kaikkea tärkeä keskustelunavaaja niin politiikan kuin käytännön työnkin saralla. Kirjan johdantoartikkelissa taustoitetaan heti aluksi kirjoitussarjan tulokulmaa: maahanmuuttoa ja muuttoliikettä halutaan tarkastella laaja-alaisessa nuorisotutkimuksen ja -politiikan kehyksessä, joka on jäänyt syrjään pelkojen ja vastakkainasettelun leimaaman turvapaikkakeskustelun tieltä. Kirjoitussarjassa halutaan nostaa esille nuorten turvapaikanhakijoiden arkikokemuksia pakenemisesta, turvapaikan hakemisesta ja uuden elämän rakentamisesta Suomessa. Nuorten turvapaikanhakijoiden arkea ja elämää tarkastellaan monien sosiaalipedagogisten käsitteiden, kuten osallisuuden, toimijuuden ja kuulumisen näkökulmista. Näiden lisäksi kirjoitussarjassa tarkastellaan ja otetaan kantaa nuorten turvapaikanhakijoiden ihmisoikeuksien toteutumiseen. Artikkelit ponnistavat lapsilähtöisesti vastaanottovaihetta elävien nuorten arjesta, jota valotetaan muun muassa nuoruuden, asumisyksikön arjen, turvapaikkaprosessin, turvapaikkapolitiikan, alaikäisen turvapaikanhakijan juridisen aseman, kotoutumisen ja kotouttamisen näkökulmista. Myös siirtolaisuusilmiötä ja sen taustoja pohditaan suhteessa nuoren turvapaikanhakijan elämänkaareen.

Piitulaisen artikkelissa "Kansainvälisen suojelun periaatteista ei voi alaikäisten kohdalla tinkiä" avataan alaikäisten turvapaikanhakijoiden oikeudellisen aseman taustoja. Turvapaikkaprosessin aikana lasten oikeuksia säädellään kansainvälisten sopimusten ja standardien sekä kansallisen lainsäädännön tasolla. Lasten oikeuksien sopimuksessa on säädetty erikseen lasten aseman huomioimisesta heidän erityisen haavoittuvuutensa vuoksi. Euroopan maiden yhteisen perustan lasten oikeudellisen aseman turvaamiseksi muodostavat kyseinen Lasten oikeuksien sopimus, YK:n ihmisoikeusinstrumentit ja toimijat sekä Haagin konventioon perustuvat eurooppalaiset standardit. Kansallisella tasolla turva- 
paikanhakijalasten asemaa säätelee lisäksi lastensuojelulaki. Piitulaisen artikkelissa kuvataan kuitenkin useita ongelmakohtia, joita nuorten turvapaikanhakijoiden oikeudelliseen asemaan liittyy.

Yksi esimerkki näistä ovat useiden vuonna 2015 saapuneiden lasten turvapaikkahakemuksia koskevien päätösten odotusaikojen venyminen, vaikka vastaanottolain 5. pykälässä linjataan lapsen oikeuksien sopimukseen viitaten muun muassa niin, että ilman huoltajaa saapuneiden lasten hakemusten käsittelyn tulisi tapahtua kiireellisesti. Turvapaikkaprosessia on myös kritisoitu esimerkiksi siitä, ettei lapsen etua ja kuulemista ole aina huomioitu riittävällä tavalla. Tähän syvennytään tarkemmin Korkmanin artikkelissa "Alaikäisen turvapaikanhakijan kuulemiseen liittyviä haasteita oikeuspsykologisesta näkökulmasta". Myös perheenyhdistämistä on hankaloitettu Piitulaisen mukaan siitäkin huolimatta, että Suomessa tunnetaan laajasti perheen merkitys hyvinvoinnille ja kotoutumiselle. Kuusisto-Arponen tarkastelee artikkelissaan "Yksin tulleiden nuorten kohtaaminen ja sosiaalinen tuki arjessa" monia vastaanottovaiheen institutionaalisten rakenteiden ongelmia. Hänen keskeinen viestinsä on se, että Suomessa tulisi kehittää uusia, sektorirajat ylittäviä toimintatapoja yksin tulleiden lasten tilanteen paremmaksi haltuunottamiseksi.

Oikeudellisen aseman lisäksi julkaisussa tarkastellaan moniäänisesti nuorten turvapaikanhakijoiden arkielämää Suomessa. Asumisyksikön arkea kuvataan muun muassa Husseinin artikkelissa "Vastaanottokeskuksen elämää ohjaajan ja nuoren silmin", jossa hän kertoo omista kokemuksistaan niin nuorena turvapaikanhakijana kuin nyt myöhemmin asumisyksikön ohjaajana. Honkasalo puolestaan kirjoittaa artikkelissaan "Osallisuus vaatii toteutuakseen turvaa, aitoa kuuntelemista, ystävyysverkostoja ja tietoa” esimerkiksi kännykän merkityksestä osallisuudelle ja sosiaalisille suhteille. Kännykällä pidetään yhteyttä ystäviin ja tuttaviin, luodaan kontakteja ja kommunikoidaan yhteisen kielen puuttuessa. Pihlaja korostaa artikkelissaan "Nuoret turvapaikanhakijat tarvitsevat monipuolista kotouttamista" kotouttamisen aloittamisen tärkeyttä jo odottamisen aikana. Maichen artikkelissa "Nuoret turvapaikanhakijat ja luottamuksen rakentuminen arjen käytännöissä" on nostettu esiin tutkimuksen kohteena olleiden nuorten sekä työntekijöiden kokemuksia ja ajatuksia elämästä vastaanottovaiheessa.

Kirjoitussarjassa, muun muassa edellä mainitussa Maichen artikkelissa, tarkastellaan nuorten turvapaikanhakijoiden arkea myös vastaanottoyksikön ulkopuolella. Tämä onkin olennaisen tärkeää nuorten täysivaltai- 
sen osallisuuden toteutumisen selvittämiseksi. Vastaanottovaihetta elävät nuoret käyvät koulua, harrastavat, hengailevat ja osallistuvat yhteiskunnassa monin eri tavoin. Täysivaltaista osallisuutta kuitenkin hankaloittavat monet tekijät, kuten nuorten turvapaikanhakijoiden ja suomalaisten nuorten välisten sosiaalisten suhteiden ohuus. Onodera ja Peltola tarkastelevat myös nuorten turvapaikanhakijoiden sosiaalisia suhteita tekstissään "Ystävyys, sosiaaliset suhteet ja nuorten turvapaikanhakijoiden poikkeukselliset olot". Sen mukaan nuorilla on paitsi viranomaissuhteita myös koulussa muodostuneita suhteita kanssaopiskelijoihin ja opettajiin. Affektiiviset tai läheisyyteen perustuvat siteet suuntautuvat kuitenkin toisaalle, kuten kotimaan perheenjäseniin, sukulaisiin ja ystäviin, sekä muihin tuttaviin ympäri Suomen ja Euroopan. Lähteenmäki kertoo artikkelissaan "Alaikäisten turvapaikanhakijoiden mielenterveyden haasteet" eron perheestä kuormittavan yksin tulleiden nuorten mielenterveyttä.

Perheistään erillään olevia nuoria varten on ryhdytty järjestämään Suomessa monenlaista vapaaehtoistoimintaa, jota myös käsitellään useassa kirjoitussarjan artikkelissa. Piitulaisen tekstissä kerrotaan Pelastakaa Lapset ry:n Lapsiystävällinen tila -projektista, jota toteuttavat Pelastakaa Lapset ry:n työntekijät sekä valmennetut vapaaehtoiset. Sen tavoitteena on tarjota kaikille Suomen vastaanottokeskuksissa majoittuville lapsille turvallinen ja mieluisa tila, "-- jossa he voivat toipua traumaattisista tapahtumista, jossa heitä kuunnellaan ja tuetaan ja heille tarjotaan mahdollisuus kehittyä ja samalla sopeutua uuteen ympäristöön”. Artikkelissa avatun hankkeen ohella Suomessa on käynnistynyt useiden tahojen toimesta monia muitakin nuoria turvapaikanhakijoita tukevia toimintoja, kuten tuki- tai kummiperhetoimintaa. Tällaiset uudet vapaaehtoistoiminnan muodot olisivat kiinnostavia tutkimuksen kohteita paitsi nuorten turvapaikanhakijoiden myös kansalaisyhteiskunnan ja -toiminnan näkökulmista. Laari ja Rummakko toteavat artikkelissaan "Ensisijaisesti lapsia?", että vapaaehtoisten aktivoituminen ympäri maan turvapaikanhakijoiden määrän poikkeuksellisen kasvun myötä on ollut uudenlainen ja myönteinen ilmiö. Sosiaalipedagogisesta näkökulmasta solidaarisuuden käsite olisi kyseisen ilmiön tarkastelussa olennainen, mutta se jää puuttumaan julkaisusta. Kokemuksia vapaaehtoistoiminnan kentiltä kuullaan myös kahdessa Kaukon, Lahden ja Nummenmaan artikkelissa: "Kun on vain tavallinen minä ja tavallinen sinä: ääniä vapaaehtoistyön kentältä" sekä "Opiskelijoiden ja turvapaikanhakijoiden yhteistyö yliopiston kolmanteen tehtävään vastaamisena”. 
Julkaisussa tarkastellaan myös ansiokkaalla tavalla turvapaikanhakijavaihetta osana nuoren elämänkaarta. Turvapaikkapäätöksen odottaminen voi johtaa Honkasalon mukaan pahimmillaan jopa elämäninnon menettämiseen samalla, kun nuori turvapaikanhakija elää erityistä aikuistumisen elämänvaihettaan. Suurpää käsittelee turvapaikanhakijoiden täysi-ikäistymiseen liittyviä sudenkuoppia artikkelissaan "Pieni ja suuri ikäero: kiistanalaiset ikämäärittelyt nuorten turvapaikanhakijoiden elämässä”. 18 ikävuoden rajapyykki johtaa muuttoon pois asumisyksiköstä ja se voi myös merkittävästi heikentää nuoren mahdollisuuksia saada myönteinen turvapaikkapäätös. Onoderan teksti "Odottamisen monimuotoisuus nuorten turvapaikanhakijoiden arjessa" syventyy välitilassa elävien nuorten arkiseen elämismaailmaan. Sen lopussa muistutetaan, että institutionaalisesti pakotettua odottelua olisi hyvä hyödyntää tietotaitojen kartuttamiseksi ja nuorten tulevaisuuden mahdollisuuksien parantamiseksi. Yksi oiva keino olisivat erään hänen haastattelemansa työntekijän mukaan oppisopimuskoulutukset.

Nuorten turvapaikanhakijoiden yhteiskunnallisen osallisuuden reunaehtojen syvemmälle tarkastelulle olisi ehdottomasti tarvetta. Kirjan lopussa esitetyt konkreettiset toimenpide-ehdotukset osoittavat sen, että nuorten turvapaikanhakijoiden vastaanottamisessa on hyvin paljon kehitettävää. Julkaisun ihmisoikeuksiin, osallisuuteen ja toimijuuteen kytkeytyvät näkökulmat herättävät pohtimaan nuorten turvapaikanhakijoiden toimintamahdollisuuksia yhteiskunnassa ja arjessaan. Martha Nussbaumin ja Amartya Senin kehittämä toimintamahdollisuuksien teoria voisikin toimia tarkoituksenmukaisena työkaluna aiheen syvemmässä tutkimisessa sekä konkreettisten toimenpiteiden kehittämisessä ja arvioinnissa. Yhdessä julkaisun toimenpide-ehdotuksessa mainitaan, että vastaanottovaiheessa tulisi ohjata ja tukea riittävästi nuorten turvapaikanhakijoiden aktiivista kansalaisuutta. Muutoin kansalaisuusnäkökulma jää julkaisussa vähäiseksi. Tämä näkökulma olisikin syytä ottaa vahvemmin esiin vastaanottovaiheen tutkimisessa ja kehittämisessä.

Kaiken kaikkiaan Nuorten turvapaikanhakijoiden elämää vastaanottovaiheessa on tarkoituksessaan onnistunut ja kiinnostava julkaisu. Teemaa lähestytään moninaisista tulokulmista, ratkaisukeskeisesti ja käytäntöön suunnaten. Artikkeleiden järjestys noudattaa niiden alkuperäistä julkaisujärjestystä, mutta kirjan kokonaisluettavuuden kannalta sisältöä olisi voinut jäsentää selkeämmin. Kirjoituksia ei ole jaoteltu esimerkiksi lukuihin, eikä sisällysluetteloa selaamalla saa vielä kovin selvää kokonaisku- 
vaa kirjan sisällöstä. Julkaisussa voisi myös olla enemmän lukijaa ohjaavia elementtejä, kuten katsaus kirjoitussarjan artikkeleihin. Informaatio on jossain määrin hajallaan kirjan sivuilla ja artikkeleissa on myös päällekkäisyyksiä ja toistoa. Toisaalta jäsentymättömyys kertonee osaltaan siitä, kuinka alkutekijöissään nuorten turvapaikanhakijoiden arjen tutkiminen vielä on. Kirjoitussarjan tehtävänä on ensisijaisesti toimia yhteiskunnallisen keskustelun avaajana sekä politiikan ja käytännön työhön suuntautuvien konkreettisten ehdotusten esittäjänä, mikä lieneekin tällä hetkellä nuorten turvapaikanhakijoiden itsensä kannalta oleellisinta ja ajankohtaisinta. Aiheen syvemmälle jatkotutkimukselle julkaisu tarjoaa informatiivisen, moniäänisen ja ajatuksia herättävän perustan. 